ANNA FRANTA*

\section{Ragusa "miasto-laboratorium" badania możliwości doskonalenia spójności i ekspresji struktury urbanistyczno-architektonicznej}

Ragusa - a "Lab City" for Investigating the Possibility of Advancement in Cohesion and Expression of the Urban and Architectural Structure

Streszczenie

Mlasta z rodowodem historycznym, mają 'dobrą tradycję' ekspresywności wielo-kulturowej. Jakie są natomiast nowe wymiary społecz. nej ekspresywności - w czym kryja się zagrożenia, a w czym tkwi szansa - miasta XXI wieku. Konieczna jest intencja skomponowania (w zasady regulujące koordynacji: formalnej, aktywności i dramaturgii powiazzan - sekwencji o różnejej ekspresywności. Przestrzenie publiczne historycznych centrów miast coraz bardziej POTRZEBUJA wsparcia w nowych przestrzeniach publicznych ,atrakcyjnych inaczej".

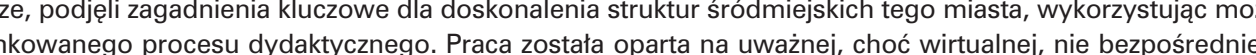
obserwacji miasta, na tropieniu jego różnorodnych problemów ale i niezwykłości, w poszukiwaniu potencjału specyficzności tkwiącego w poszczególnych rejonach działań - również w tych, pozornie mniej wartościowych. Ragusa przeobraziła się w „miasto-laboratorium”. Stała się miejscem, fascynującego projektowego eksperymentu, mającego na celu identyfikacjej strategii promujacych rewitalizację mia-


cja - kiedy potrafimy przyjać nowe perspektywy dla tej, z intenciji, twórczej obserwacji. Istotne jest, aby taki "idealistycznn" wkład stał się specyfiką i tożsamością miejsca, czyli lokalnych społeczności i ich potrzeb w zakresie zindywidualizowanej ekspresj.

Abstract

Cities with history have 'a good tradition' of multicultural expressiveness. What are, however, new dimensions of social expressiveness;
where are threats lurking, and where do opportunities reside for the 21st-century city? What is necessary is an intention of compositio (in contrast to the quite commonly encountered intention of lack thereof) of parts and of the whole, and the vision of the 'face' of the city in entalls, ac to public spaces, attractive somewhat differently. They also call for studies of a designing nature. In Ragusa, starting from the Re-use Ragusa 2014 International Workshop, architects-researchers took up issues of key importance for the advancement of inner city structures of this place, making use of the opportunities offered by a properly directed didactic process. The work was based on a thorough - albeit virtua indirect - observation of the city, on the investigation of diversified problems, but also singularities, in search of the potential of specificity residing in individual areas of activities, including the ones which are seemingly less valuable. Ragusa transformed into a 'lab city". thecame a place of a fascinating designing experiment, aimed to identify strategies promoting revitalisation of the city from the inside, starting from the resources and the potential it offers. The goal here was to notice and improve the values and opportunities presented contribution be useful, offering an array of possible activities and opening up fields for further discussions by creating good models compliance with the specificity and identity of the place, that is local communities and their needs in terms of individualised expression.

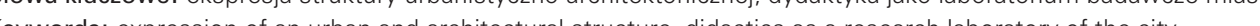

Miasto XXI wieku jako miejsce korelacji zindywidualizowanej ekspresywności alności kulturowej - własnego, niepowtarzalnego, związanego z miejscem i tradycją ksztaltu przestrzeni, w której zyjemy i swiata wartosci, które tworzymy. Traktowane dynamicznie dziedzictwo, obejmujące: przeszłośc dzisiejszy do niej stosunek $i$ to, co wnosi terazniejszos dodając elementy nowe z myslą o współczesności i przy-


sci cywilizacji technicznej na rzecz "kultury miasta" (1) doskonalenia przestrzeni publicznej, jej ekspresywności piękna, będącego miarą kultury i aspiracji mieszkańców. Dtoczenie przestrzenne nie ma mocy sprawczej. Ma chacze wspomagajace: sprzyjajace lub utrudnajaeptymalnie pobudzato indywidualna 'd wartych w nim informacii, a nie przeciażo i dezinformowato ich nadmiarem, sprzeczościa nieczytenościa Stad tė̇ celowość komplementarności poszczególnych sekwencii przestrzeni, ich synergiczne - wzajemnie do wartościowujace - skomponowanie. Uwarunkowania oddziaływania otoczenia przestrzennego na psychike ludzka sprawiaja ż intuicyjie niedyskursywnie pojmujemy mowe przestrzeni". Ale dzieki nim równiez możemy się tą mowa świadomie i celowo posługiwać oraz w sposób pogłebiony i nie tylko intuicyjny ja 'czytać'. Analiza semiologiczna przestrzeni (2), każe zwracać uwagę na znaki i wszystkie możliwe ich znaczenia - jest ostrożnym poszukiwaniem, skłaniającym, by nie zadowalać się pierwszym widocznym znaczeniem: zachęca do takiej 'lektury" przestrzeni, ktora ujawnia jak najwięce kwiących w niej możliwosci i interpretacji. Przestrzen architektoniczno-urbanistyczna jest, ze względu na sprzęzone oddziaływanie czlowiek - otoczenie przestrzenne - człowiek, sytuacją znakową. Rożny jest jednak stopien jej intencyjności. Cechą dobrze uformowanej przestrzeni publicznej jest, intencjonalne wlaśnie, komponowanie znakow symultanicznie wypelniających pole widzenia w przekaz znaczący: stymulujący indywidualny odczy

Efektywnie doskonalace oddziaływanie na strukturę miasta polega na 'graniu' tym, co jest dane i 'wygrywaniu' na recz rozwązania cech tego co jest dane (obiektywnych Stych ukrytych, pozyty nych ale równieź negatywnych). S zlogika dramiejur la winterakcie z proces teatru żcia codziennego", dopiero w jej trakci i osiagajacej p e tn i e ekspresil wháci w jebie urode miejkości. To rola - autorkiego pojecia (3) - reżyserii przestrzeni (4).

Konieczna jest wiec intencja skomponowania (w przeKonién je do dość powszechnej intencii braku skomponowania) cześci i całości oraz wynikająca z niej wizja 'oblicza' przestrzeni publicznej miasta i dalej - wspomagające jej urzeczywistnienie - zasady regulujace (merytoryczne, organizacyjne, prawne), $w$ tym nadrzedna dla realizacji tej intencji konstrukcja reżyserska trój-zwiazku: koordynacji formalnej, koordynacji aktywności i koordy

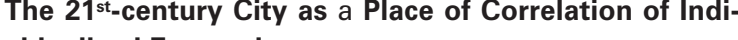

National identity results from cultura and individualty - the very own and unique shape of space we in habi relating to own and unicue shape of the world or values wo create. Herlige grasped dynamically, cons and what the present brings, adding towards ments with the present day and the future in mind is in fact an ability to make use of the opportunities offered by the technical civilisation for the good of the 'urban culture' (1) - the advancement of the public space, its expressiveness, beauty, as a measure of the culture and aspirations of city residents.

ment has no causative power. It has only an auxiliary meaning: facilitating or hindering. Hence the responsibility for providing conveniently, so that could optimally enhance individual interpretation of information it contains and does not overload and confuse with is excess, contradiction, illegiblhy. Hence also the legitimacy of complementarity of individua ale spatial environment has upon the human mind cccourt for the fact that we intuitively 'non-discursively comprehend the language of the space'. But thanks to them we can also use this language consciously and purposefully and 'read' it in a much more profound way, not only intuitively. The semiological analysis of space (2), orders us to pay attention to signs and all possible meanings to be satisfied with the first meaning one perceives; encourages to 'read' the space so as to reveal as many possibilities and interpretations embedded in it as poss. man - spatial environment - man, he architectural and however, varies. One of the features of a welldesigned public space is a quite intentional composition of signs which simultaneously fill the view and transform it into a meaningful message: a stimulating individual percepion, understanding, and reaction of each recipient.

An effectively enhancing impact upon the urban structure consists in 'playing' with what is there, what is given, and 'Winning for the good of solving the properties of what is given (the objeclive and the hidden ones, the positive and the native ones, too). It consciously grades the means effiche of the dy in a strictly defined moment, following the logic and urban space - ready to enter the interaction with the process of 'the theatre of the everyday life', but only during it reaching the full expression: the inherent beauty recting space. (4).

Therefore, what is necessary here is an intention of composition (in contrast to quite a widespread intention of the lack of composition) of parts and of the whole, and a vision of the 'face' of public space that results from a (s) of this intention, namely the directing structure of the 
nacji dramaturgii powiązań - sekwencji o różnej ekspresywności.

Miasta, te z rodowodem historycznym, maja 'dobra tradycję ekspresywności wielo-kulturowej. Jakie sa natomiast nowe wymiary spolecznej ekspresywności - w czym kryją się zagrożenia - a w czym tkwi szans - miasta XXI wieku, potencjalnie, postindustrialnego miasta kulury iwiedzy - kultury, Ktora " jest próbą zmuszenia dziejów, żeby służyły wartości" (H. Elzenberg).

\section{Wsparcie dla historycznych serc miast}

Istotnemu rozszerzeniu ulega samo pojęcie „historica center" współczesnych miast. Nie odnosi się ono już tylko do cennych obszarów zabytkowych, ani do otaterytoria je XIX-wiecznych dzielnic będących efektem $z$ poczatkani uprzemystowienia i masomego naptyu $z$ początkami uprzemyso

Pojęcie historycznego centrum rozszerzyć można, i należy, o póżniej powstałe struktury, których cechy takie jak milin. koncentracja i sóżnodnośc funkcji, wyrazistośc formy urbanistycznej, obecnosc $w$ swiadomosci mieszkankow, korysthe położenie $i$ in. nadają im znaz najcenniejszym zabytkowym „sercem”. To 'serce' z ra$z$ najcenniejszym zabytkowym "sercem". To "serce" $z$ ra-
cji swej unikalności bywa ponad miare obciazzane zarówno ruchem turystycznym jak i róźnege rodzajaju okazjono ruchem turystycznym jak i roźnego rodzaju okazjocharakteru, a przede wszystkim, do wartości kulturowe miejsca.

Przestrzenie publiczne historycznych centrów mias coraz bardziej POTRZEBUJA wsparcia w powiązanych z nimi w ciągły system, a łatwo dostępnych (w pieszym dojściu, rowerem, krótkim dojazdem komunikacja masową) nowych przestrzeni publicznych „atrakcyjnych inaczej". Czyli poszerzających możliwości funkcjonaln i oferujących niemożliwą do zastosowania w najcenniejszych zabytkowych obszarach, nową typologię przestrzenną.

Idea zrównoważonego rozwoju która, od końca XX wieku, zdominowała myślenie o mieście, skłania do rewizji podejścia do rozwoju miast: $z$ tego polegającego na rozprzestrzenianiu terytorialnym na to, zwracające się ku
doskonaleniu istniejacych już struktur miejskich - jako doskonaleniu istniejących już struktur miejskich - jako
efektywniejszej środowiskowo i społecznie strategii rozefektywniejszej środowiskowo i

woju miasta - do filozofil re-use. izainteresonani in niej zagospodarowane, takie jak obszary przeróniete infrastruktury technicznej i komunikacy pizoj czy rejony opuszczanej zabudowy przemysłowej i magazynowe czy też niesprecyzowane wewnetrzne i zewnetrzne kra wedzie" - majace szczególnie wysoki potencjał rozwo ju przez doskona sacie" na drodze catosciowej strategi ju przez doskonalenie" na drodze całosciowej strategi
przekształceń funkcjonalno-przestrzennych. Miasta są wrażliwe, a i ich życie czasami jest "poprzecinane" katastroficznymi wydarzeniami. Wywołane czynnikami naturalnymi lub przez działalność człowieka, stanowią cezurę czasową między przeszłością, która kończy się dramatycznie i przyszłością, pełną nadziei na doskonalące odrodzenie. Na zrealizowanie celów, któ- triple relationship: of formal coordination, coordination nections - sequences exhibiting various degrees of expressiveness.

Cities boasting a historic lineage have a good tradition of multicultural expressiveness. And what are the new dimensions, risks, and opportunities of the social expres-

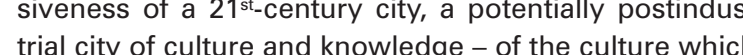
"constitutes an attempt at forcing history to serve the value" (H. Elzenberg)?

Support for Historical City Centres

The very term of the historical centre of contemporary cities has been extending. It no longer refers merely to valuable historic sites nor to $19^{\text {th-century districts that su- }}$ ound them, the effects of the territorial expansion of cirles associated with such phenomena as the beginning of industrialisation and massive influx of people to cities. The term of historical centre can, and in fact should, be extended to include later structures, whose such properties as e.g. concentration and diversity of functions, distinctiveness of the urban form, presence in the aware the significance of local centres in the complementary relation with the most valuable historical 'heart'. This 'heart', due to its uniqueness, is often overburdened with the tourist traffic, as well as with all sorts of occasion activities, not always adequate to the nature of the place, but most of all to its cultural value.

More and more often public spaces of historical city centres NEED support on the part of new public spaces, combined with them into a continuous system and eas ily accessible (for pedestrians, cyclists, only a short ride way for public transport users), attractive in a differen way'; broadening functional opportunities and offerin new spatial typology, impossible to be adopted in the

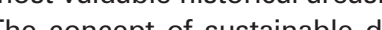

列 century, inclines to revise one's approach to the the 20 ment of cities, from the one consisting in the territoria

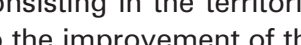
existing urban structures as a more effective city development strategy in environmental and social terms - to the philosophy of re-use.

What becomes the subject of concern of municipal authorities and city residents, as well as the subject of inerest of investors, are previously developed areas, suc as areas of overgrown technical and transport infrastruc ture, or areas of abandoned industrial and warehousing structures, or finally undefined inner and outer 'edges through improvement' along the lines of a holistic strategy of functional and spatial transformations. cected' with quite catastrophic events. Brought interby natural causes or due to man's doing, they constitute landmarks dividing the past, which has a dramatic ending, and the future, full of hope for enhancing revival; for achieving goals which - even if only imagined by a part of the society - are a driving force for successive archtectural and urban revival. rych samo wyobrażenie, nawet tylko przez częśc spoleczenstwa, jest siła napędowa sukcesywnej odnowy architektonicznej i urbanistycznej.

Jednak istnieje również inne zjawisko, które zagraż zyciu miasta. Jest tak samo katastroficzne, lecz mnie nagłe, utajone, trudniejsze do odwrócenia, a z czasem kończy się uruchomieniem nieodwracalnego proces erozji zarówno w strukturze zbudowanej jak i społeczne;. Chodzi o opuszczenie, nieużytkowanie, utratę witalności. Od przełomu XX i XXI wieku systematycznie uderza to zwlaszcza w duże obszary produkcyjne, dawniej peryferyjne teraz juź srodmiejokie, i ma często degradujący wpływ na serce miasta - centra historyczne. W szcze golności na te, korych nie udalo się odnowic, w tak iodwiedzajacych, wynikajace z postepu gospodarczego

Wost w ty paradoksalnego, bowiem „zawartośćc i przestrzenna centrów historycznych pojbardziej autentycznym wyrazem tożsa-

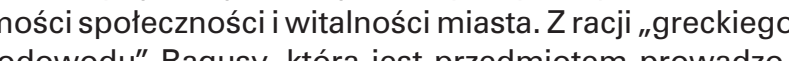
dowodu" Ragusy, która jest przedmiotem prowadzonych tu rozważań, warto przypomnieć, że „Arystoteles, nych i intelektualnych cnót dla dobrego życia ludzi wy raża implikacje dla architektury i urbanistyki" (5). A wiec powinno być miejscem o zwartej strukturze, w którym skupiły sie wartości kulturowe i obywatelskie, w opozycji do rozproszenia dzielnic zewnętrznych. Te często charakteryzują się sektorami mieszkalnymi, rozrastajacymi się zgodnie z czysto komercyjną logiką deweloperską, pozbawionymi przestrzeni publicznej, niezdolnymi do przekazania mieszkancom poczucia przynależności właściwego rdzeniom miast: najstarszym formacjom urbanistycznym ich struktury.

Wzrost ekonomiczny, napędzany w ostatnich dziesięcioleciach równiez tezą, pozornie prawdziwą, o nieograniczonej dostępności zasobów, sprzyja marnotrawieniu wolnych trenów, zasobu zawsze słabszego i nieodnawialnego. To doprowadza do stopniowego opuszczania najbardziej delikatnych obszarow centrów historycz nych, tych charakteryzujących się biedną i gęstą zabudową, skladającą się z jednostek mieszkaniowych zbyt zaspokoić potrzeby - wolnej przestrzeni i prywatności wywołane przez rynek.

we nich należy

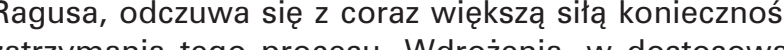
hiu do specyfiki umarunkowán miejsca, odpowiednich środków mogacych spowodować jego rzeczywiste od wrócenie. Nowa koniunktura gospodarcza wywotuje też potrzebe zrównoważonych działań, nie tylko równiez" ale ułaśnie" w stosunku do funkcii mieszkaniowej, która warunkuje witalność miasta. Ta tendencja coraz częściej rozpowszechniana, jeśli zostanie wdrożona do polityki miejskiej, w sposób odpowiedzialny odważny, może sprzyjać systemowemu doskonaleniu struktury skierowanemu na ponowne użycie (re-use) i tym samym na re-witalizację pustoszejących centrów historycznych (6)
There is, however, another phenomenon which threatens the life of the cily. Equally catastrophic in natue, albeit less sudden, hidden, more difficult to reverse, with time it ends with launching an irreversible process of erosion in the built structure, as well as in the social one. This phenomenon is the abandonment, non-use, loss of

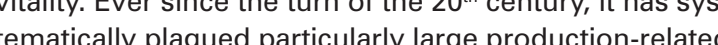
areas, formerly located in the suburbs and central now. and it often has a degrading effect on the heart of the city - its historical centre. It refers particularly to cities which failed to be renewed so as to satisfy new needs of their residents and visitors, resulting from economic and social progress.

paradox here, as the functional and spatial 'content' of historical centres should be a possibly most authentic expression of the social identity and the vitality of the city. Due to the Greek lineage of Ragusa, which is the subject matter of the deliberations contained herein, it is worth remembering that "Artistotrality of moral and intellectual virtues for good lives of teople expresses implications for architecture and ur ban planning" (5). Therefore, it should be a place with compact structure, bringing together cultural and civic values, in opposition to the dispersion of outer districts. The latter are often characterised by residential sectors. sprawling according to developers' purely commercia logic, deprived of public spaces, uncapable of providing heir residents with the sense of belonging specific to urban corm their structure. Economic growth, in recent decades driven also by seemingly true thesis on the unlimited availability of (avaste of available lands, which This brings which is ever weaker and non-renewable. hat acteris by poor and dense devopment consisting of ousing units too tightly spaced and not big enough to satisfy the needs of free space and privacy, evoked by the market.

Hence in many such cases, Ragusa being one of them, the need to stop this process is recognised more and more ardently. It becomes apparent that relevant meaverse it to be implemented in order to actually reevokes a need of sustainable activities, not only 'also' but 'precisely' regarding the residential function, which conditions the vitality of the city. This tendency, more and more fervently promoted, if implemented in the urban policy in a responsible and bold way, may foster systematic improvement of the city structure oriented gradually abandoned historical centres (6).

\section{Topics, Thorough Designs} Dextended understanding thereof and of the challenges they face is

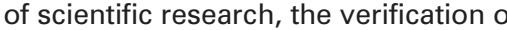
Which requires design-related studies, too, in order to measures. 
Re-use Ragusa - kontynuacja: rozszerzone obszary, aty, dogłębne projekty

Problematyka historycznych centrow - w rozszerzonym ich rozumieniu - i stojących przed nimi wyzwań jest przedmiotem badań naukowych, ktorych weryfikacjadla skuteczności i bezpieczenstwa działan realizacyjnych - wymaga również badań o charakterze projektowym. W przypadku Ragusy - poczynając od Międzynarodowych Warsztatów Re-use Ragusa 2014 - architekci-badacze, podjęli w procesie dydaktycznym, zagadnienia badawcze, $w$ skali urbanistycznej $i$ architektonicznej, kluczowe dla doskonalenia struktur sródmiejskich tego miasta. Wykorzystując możliwości, odpowiednio ukierunkowanego procesu dydaktycznego w nauczaniu urbanistyki $i$ archisckstr, do testowania i weryfkowania hipotez badawczych stawianych pod katem ich potenJemén przestrenych miasta oraz otwierania nowych pól badawczych w tym zakresie. oz owiey ia n

por tu laboratorium-studio projektowe na uczelni architektonicznej. W waprzygotowanie i poziom umiejetności studentów) sfor-

II. 1. Tektoniczna struktura Ragusy / Tectonic structure of Ragusa, http://www.provincia.ragusa.it

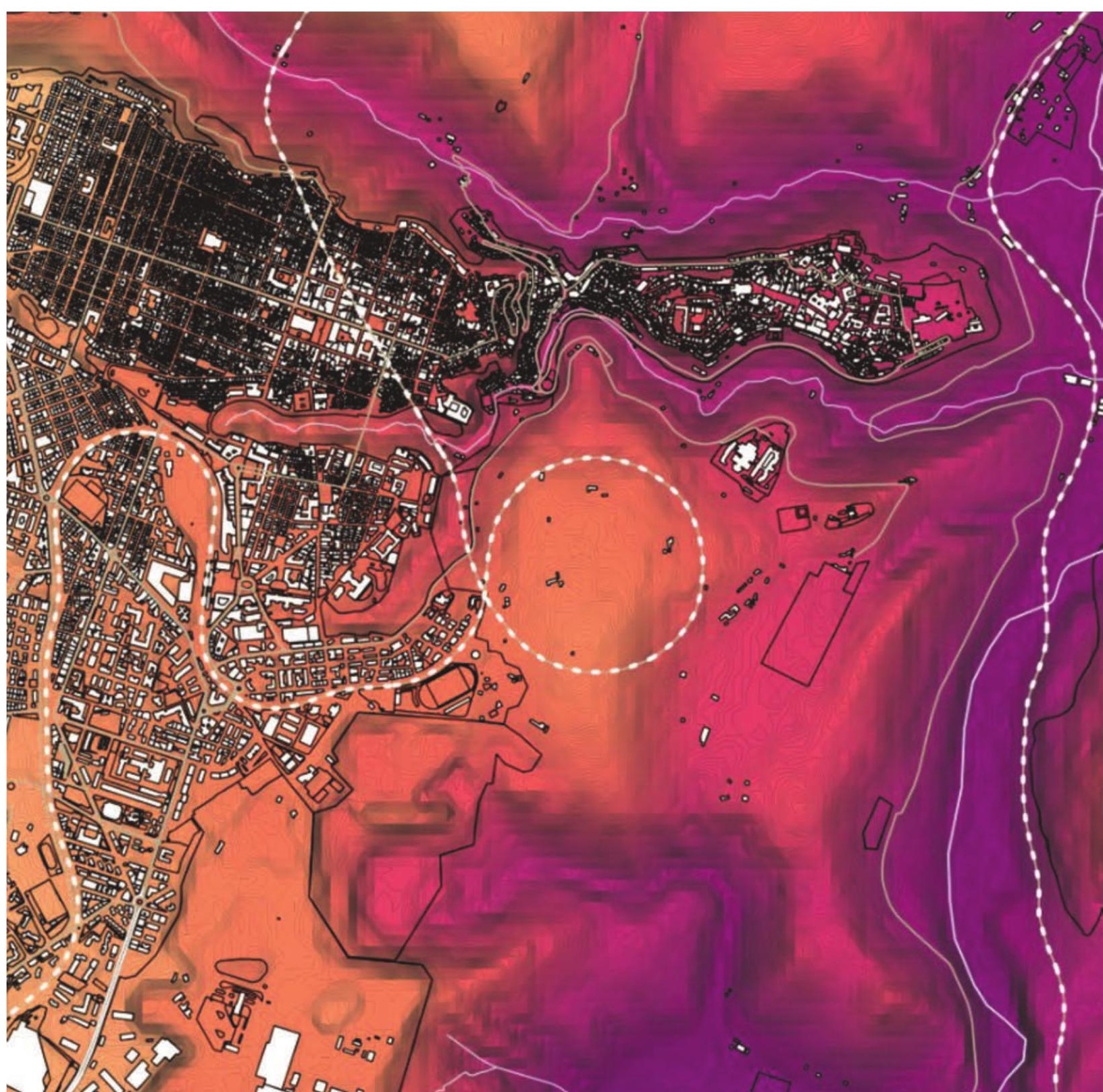

mułowane z punktu widzenia potrzeb badania naukozwykle jeden semejo nawet kilkunastu wariantach. To $w$ warunkach tak praktyki profesjonalnej jak i działań planistycznych podejmowanych przez samorządy, jest z reguły niemożliwe ze względów proceduralnych, czasowych i finansowych. Laboratorium badawcze, jakim jest proces dydaktyczny na Wydziałach Architektury Wyższych Uczelni, to również "dyskurs inteligencji" (7) (8). Ludzi w różnym wieku, którzy wykorzystuja odmienny, osobisty wgląd W miasto, doświadczenie i rozznorodną wraźliwośc, wnosząc inne niz powszechne sposoby myślenia i definioWania potrzeb stawianych miejskiemu srodowisku życia. Często cechy miasta ukryte są przed percepcyjnym punktu widzenic - whónie no spojzenie ,z zewnatz - udaje sie zidentyfikować te mocne strony, na których można się $w$ procesie transformacji oprzeć.

Ragusa, znana jest jako symboliczny przykład mista, które było w stanie wyciagnać wnioski z trzesień ziemi, które zniszczyły ja w 1693 roku oraz stworzyć ziem dla odrodzenia i skonstruowania nowej wielopłaszczyznowej tożsamości która jednoznacznie kojarzymy ze względu na jej złożona, znakomitą strukture architektoniczną i urbanistyke późnobarokowa - uznaną w 2002 roku przez UNESCO za dziedzictwo ludzkości.

Równocześnie Raguse cechuje ewidentny brak infrastruktury, placów i ogrodów publicznych wewnątrz obecnej tkanki, co jest wynikiem procesu stopniowego zagęszczania i nasycania siatki planimetrycznej oraz braku wdrożenia dwóch planów regulacyjnych, które w latach 1880 i 1930 probowały wprowadzic, opartą na schemacie siatki izomorficznej, hierarchie i przestrzenie referencyjne dla róznych dzielnic.

Konfrontacja tych planów z aktualnym stanem struktury miasta sugeruje interwencje, które można nazwać "m krochirurgią miejską" czy "akupunkturą urbanistyczną". Maja one na celu np. przedefiniowanie relacji między blokami i utworzenie sieci niewielkich przestrzeni otwa tych i usług publicznych, przewaznie uzyskanych przez przerwanie ciągłosci masy zabudowy o bardzo złym stanie technicznym lub nieadekwatnym do miejsca gabarycie.

W każdym temacie urbanistycznym, dotyczącym Ragusy, prowadzonym w Zakładzie Ksztattowania PrzestrzeKrakouski, w operciu o generalny zakres problemu do rozwiazania i wspólny zasób materiatów wyj́ćciou do celem zadá projektowych jest skoncentrowanie proaktywnych umiejetności studenta, czasem grupy, czasem miedzynarodowej grupy roboczej, na tym aby odnaléc ens miejsca. Skoncentrować sie na "miejscu" - jego istocie i sposobach jego re-definicii, bez utraty tożsamości. Badać - za pomoca różnych metodologii analizy i nowych rozwiązań projektowych, adekwatnych do problemów zidentyfikowanych w różnych kontekstach urbanistycznych i środowiskowych. Wnieść do projektu urbanistycznego i architektonicznego nowa ekspresje komplementarna do kontekstu. Wypracować innowacyj ne i multi-dyscyplinarne walory, w ktorych idee tkwiące also constitutes 'a discourse of intelligence' (7) (8). It is who contribute with their ways of thinking and of definIng the needs to be fulfilled by the urban habitat, different than usual. Properties of cities are often hidde from the perceptive habits of their residents, and only change of perspective, perception from outside, enfoundation for the transformation process.

Ragusa is known to be a symbolic example of a city


which destroyed it in 1693 and to create conditions for the revival and building of a new multifaceted identity, which we are clearly aware of due to its excellent complex late Baroque architectural structure and urban planning, in 2002 recognised by UNESCO as human heritage. Simultaneously, Ragusa is characterised by the evident lack of infrastructure, squares, and public garden within its present tissue, which results from a process of gradual densification and saturation of it planimetric grid and from the fallure to implement two regulatory plans, which in 1880 and 1930 tried to introduce a hir
and reference spaces for individual districts.

Confrontion of these plins with the current condition of the city structure suggests interventions which could be referred to as 'urban microsurgery' or 'urban acupuncture'. They are targeted at e.g. redefining the elationships between blocks and creating a network of small open spaces and spaces of public services, usually achieved by breaking the continuity of the sequence of buildings in a very bad technical condition or in sizes inadequate to the particular location.

In each urban planning topic relating to Ragusa and lackled at the Division of Public Spaces for Movemen Faculty of Architecture, Cracow University of Technology basing on the general scope of the problem to be the active skills of a student, at times a group, at times international working group, so as to find the sense of the place. To concentrate on the place itself - its essence and methods of redefining it, without losing its identity. To investigate it by means of different methodologies of analysis and new design solutions, adequate to problems identified in different urban and environmental contexts. To introduce new expression to the urban and architectural design, complementary to the contex. To develop innovative and multidisciplinary values, in which the concepts already embedded in the city structure, the sensitive data of its actual reality, and the experience of designers (students and teachers) meet in a proactive and multifaceted vision. It is not about conas hort period of time (as it is the case in a workshopl. but instead spreading the work over the entire semester, which imposes a thorough examination of the existing conditions, as well as a search of a synthesis in which different points of view and variant approaches during the first stage of working on the project can complemen each other, collaborate, so as to eventually reach the design purpose defined in a specific task.

Without simplifying the complexity characteristic for the historical centre as well as the entire subsequent urba 
już w strukturze miasta, wrażliwe dane jego realnej rzeczywistości i doświadczenie projektantów (studentów i dydaktyków) spotykają się w proaktywnej i wielopłaszczyznowej wizji. Nie koncentracja pracy analitycznej iprojektowej w krótkim czasie ( jak w przypadku warsztatów) a rozłożenie jej na cały semestr, zmuszają do pogłębionych badań uwarunkowań ale i szukania syntezy, w której różne punkty widzenia i wariantowe podejścia w pierwszej fazie pracy nad projektem, moga „komponować się" - współdziałać, aby ostatecznie osiagnąć wymagany (określony postawionym zadaniem) cel projektowy. Bez upraszzzania zlożonosci, ktora charakteryzuje historyczne centrum jak i cały pózniejszy układ urbanistyczny Ragusy, wskazane strategie działan, czy to punktowych czy obszarowych, mily na celu zing growne dostosowanie adaptacji uzupelnien zabudowy oraz przestzeni publiczdostepnó́ci danego obszaru. Rómnie istotne było zachowanie (i wzznononie znaków tożsamości architektury i formy urbanistycznei oraz stworzenia rozwiazá sprzyja jacych stworzeniu bezpieczego obszaru w odnies siudo ryzyka sejsmicznego i niestabilności hydrogeonesieniu do Studenci stymulowani - sposobem postawienia zadania - do przyjecia interdyscyplinarnego punktu widzenia i rozumowania, zastanawiali sie nad przyczynam dekadencji poszczególnych części miasta. Przy pomocy specjalnych narzedzi, zarówno klasycznej analizy urba nistycznej jak i analizy problemowej, skupionej na potencjale środowiska mieszkaniowego i wreszcie samego projektu, badali uwarunkowania i wyzwania procesu rewitalizacji - określając rolę ich koncepcji przekształcen funkcjonalno-przestrzennych $w$ tym procesie.

Cała praca została oparta na uważnej, choć wirtualnej, nie bezpośredniej, obserwacji miasta oraz na tropieniu jego rozznorodnych problemów ale i niezwykłosci, w poszukiwaniu jego klmatu jako calości, ale i potencja specyficzności tkwiącego w poszczególnych rejonach działan - równieź w tych pozornie mniej wartosciowych Młodzi projektanci nie zostali zaproszeni do ćwiczenia architektonicznego ekshibicjonizmu - raczej innowacyjne go racjonalizmu. Bo choć nie wiele można dodać do juz W petni ukończonego miasta jakim jest historyczne cen trum Ragusy, to mangnes dzialan - zWlaszzza w konwencji ",badawczego laboratorium dydaktycznego" - istnieje, a w przypadku lokalizacji poza scisła tkanka historyczna, jąc wydobyć zasoby już obecne w mieście, ukazując i wykorzystując jego ukryte potencjały i energie.

Podejmowane tematy dotyczyły w równej mierze zabudowy jak i przestrzeni otwartych. Wszystkie wytyczne strategiczne wprowadzone $w$ tym zakresie zakładały analizę związku pomiędzy przestrzenią publiczną, a przestrzenia prywatn oraz zwizzku pomiedzy powierzchnimi zadaszonymi i powierzchniami otwartymi, w poszukiwaniu przestrzeni pośredniej, tak aby podniość poziom jakości środowiska mieszkaniowego w konkretnych uwarunkowaniach klimatycznych Ragusy.

\section{Ragusa "miasto-laboratorium"}

ktycznego, Ragusa przeobraziła się w „miasto-laboratorium”. Stała się miejsce, layout of Ragusa, the defined strategies of actions, focusadjustment of the development adaptations, additions, and public spaces to the current and emerging residential needs and the needs relating to the accessibility of a specific area. Maintaining (and enhancing) the signs of identicy architecture and of the urban form and deve oping solutions fostering the creation of a safe area in was equally important.

The students, stimuled to adopt a multidisciplinary point of view and understanding by the way the task is defined, were pondering on the causes of the decadence of individual parts of the city. By means of special tools, both of the classical urban analysis and problem analysis, focusing on the potential of the housing environmen and eventually of the design itself, they examined the conditions and challenges of the revitalisation process, determining the role of their concept of functional an spatial transformations in this process.

The entire work was based on a thorough, albeit virtua and indirect, observation of the city and on investigating its climete a a who buts but a of the potential of spectficity inherent in individual areas of activities, also the ones that seem to be less valuable.

The young designers were not invited to practise arpractise arAlthough there is not much that can be added to the already fully completed city that the historical centre of Ragusa undoubtedly is, there is still the margin of the activities, particularly in the convention of a 'didactic research laboratory', and it is quite wide for locations beyond the strictly historical tissue. The works progressed in line with the induction method, with the intention to bring out the resources already existing in the city, displaying
ergies.

The undertaken themes referred equally to built-up and open spaces. All strasegic guidelines introduced in the respect assumed an analysis of the rationship betwis the public space and the private space, as well as the relationship betwe in search of an intermediate space, so as to boost the quality of the housing environment in specific climatic conditions of Ragusa.

\section{Ragusa - 'a Lab City'}

During the didactic process, Ragusa transformed into a 'lab city'. It became a place of a fascinating designing experisy, almed to identify strategies promoting th revitalisation of the city from the inside, hence beginning reventis.

course and diploma projects, following the principles described above, was modified for each year and each type of designing classes, over the several years of exdirectly addressed actual urban and architectural topics, in the atmosphere of confrontation and intensive and organised work. All the projects attempted to obtain answers to general
problems of the city and to specific problems of a given fascynującego projektowego eksperymentu, mającego na celu identyfikację strategii promujących rewitalizacje miasta od jego "Wnętrza," a wiec zaczynając od zasobó potencjału.

Ważne jest, że dobór przedmiotu projektów kursowych I dyplomowych, podążając za opisanymi powyżej pryn cypiami, byl modyflowany dla kazdego rocznika i kazdego typu zajęć projektowych - w kilkuletnim okresi eksperymentowania" ze strukturą miasta.

Studenci zajmowali się w sposób bezpośredni rzeczywistymi tematami i problemami urbanistycznymi i arch ektonicznymi, w atmosferze konfrontacji oraz intensywnej i zorganizowanej wspołpracy.

Wszystkie projekty próbowały uzyskać odpowiedzi na ogolne problemy miasta oraz na konkretne problem danegón kaźdej lok przede wszystkim dotyczyly: wazne i topograficznei, zwiazku z systemami środowskowymi dwóch dolin oraz połączeń z innymi czésiam miasta.

Poza tymi zagadnieniami, ze szczególna starannościa wzieto pod uwage mobilność Racjonalizacia indywiduwzięo pod uwagego jest warunkiem wstepnym dia odzyskania przestrzeni publicznej dla interakcji społecznej oraz dla promowania zrównoważonych środowiskowo a efektywnych połączeń. Niezależnie od postawionego zadania, projekty wskazały potrzebe wprowadzeni do istniejącej siatki ulic i uliczek, hierarchii użytkowani oraz formowania jednostek sasiedzkich, o ograniczonym ruchu, zaopatrzonych we własne usługi, aby podnieś niewyraźną ciaggłość przestrzeni publicznej, spójność przestrzenną zabudowy (świadomie zwartej lub rozlużnionej) i wzmocnić poczucie przynależności tożsamości mieszkańców.

Została zbadana formalna struktura istniejącej zabudowy, aby zrozumiec możliwośc transformacji typologi Poszukiwania rozgęszczenia tkanki istniejącej związane były ze studiami gabarytów na rzecz polepszenia oświetlenia i wentylacji wnętrz kwartałów, co może sprzyjać transformacji społecznej dzielnic. Przezwy ciężaniu degradacji i gettyzacji przez wprowadzenie zintegrowanych zmian programowych i funkcjonalnych, podnoszących jakośc i atrakcyjność środowisk mieszkaniowego, przy zalożeniu jego demokratyczne otwartości dla odbiorców o zróżnicowanym statusi

Po za tym, kluczowe było podkreślenie potrzeby przyaceno strukturalnego zwiazku między miastem, $z$ dwóch dolin zamknietych dzisiaj ciagiem frontów bu dynków zbudowanych na terenach o wysokim ryzyku sejsmicznym. Przywrócenie jego przynależności do ca tego miasta: na północy jako tla krajobrazowego, od poludnia jako przestrzeni korzystania z natury i ponownie odkrytego rolnictwa.

Siła konkretnych tematów i wolność w zmierzeniu sie z nimi w pozytywnym duchu innowacyjnych poszukiwań, uwidacznia jak ważne jest postrzeganie problemów z różnych punktów widzenia, które czẹsto oferuje nam sama rzeczywistość, jeśli chcemy ją zrozumiec i polepszyć area, which predominantly pertained to: conditions of each location, its morphological and typographic characteristics, its relationship with the environmental sysems of two valleys, and its connections with other parts of the city.

Besides these issues, the attention was focused on mo pre Rationalsation of individual car tratic constiutes interactions and for prom tive connections. Regardless of the task the designs pointed to the need to introduce a hierarchy of use and forming of neighbourhood units within the existing grid of streets and alleys, with limited traffic, provided with their own services, so as to enhance the blurred continuity of the public space, the spatial cohesion of the development (consciously compact or loosened), an to strengthen the sense of belonging and identity of residents.

The formal structure of the existing development was examined in order to understanding the possibility of transforming its typology. The search of ways to reduce the density of the existing tissue was connected benefit of improving the lighting and ventilation of bor interiors, which may foster social transformation of city quarters and help to overcome their degradation and ghettoisation by means of introducing integrated programme and functional changes boosting the and attractiveness of the housing environment, assuming its democratic openness towards recipients with a diversified economic status.

Furthermore, it was of key importance to highlight the need to restore the structural connection between the city and its natural surroundings consisting of two valleys closed today with a sequence of building fronts erected on lands exhibiting a high seismic risk. To restore its affiliation to the entire city: as landscape backgenefiting from the re-discovered agriculture to the south.

The strength of specific topics and the freedom in facing them in a positive spirit of innovative pursuits illustrates how important it is to perceive problems from different points of view, which are often offered by the very
ity, if one wishes to understand and improve it.

Personal experiencing of Ragusa and getting to know it virtually, as well as creative work on its structure allows students to prove to themselves, and in their imagina tion to city residents, too, that positive thinking abou an urban and architectural design may create perspecives enhancing the already existing resources, consequently and with the ability to adjust to the conditions dentity of the city through sustainable proposals and

This way, a unique opportunity emerged: to explore fields where the necessary repair plan should be deveoped, as if simultaneously, so as to revitalise the city and allow its residents to reclaim it. It should protect and develop this priceless value it already holds in its clearly visible and precise form of a compact city - now in its heart, and eventually in its entire structure. 


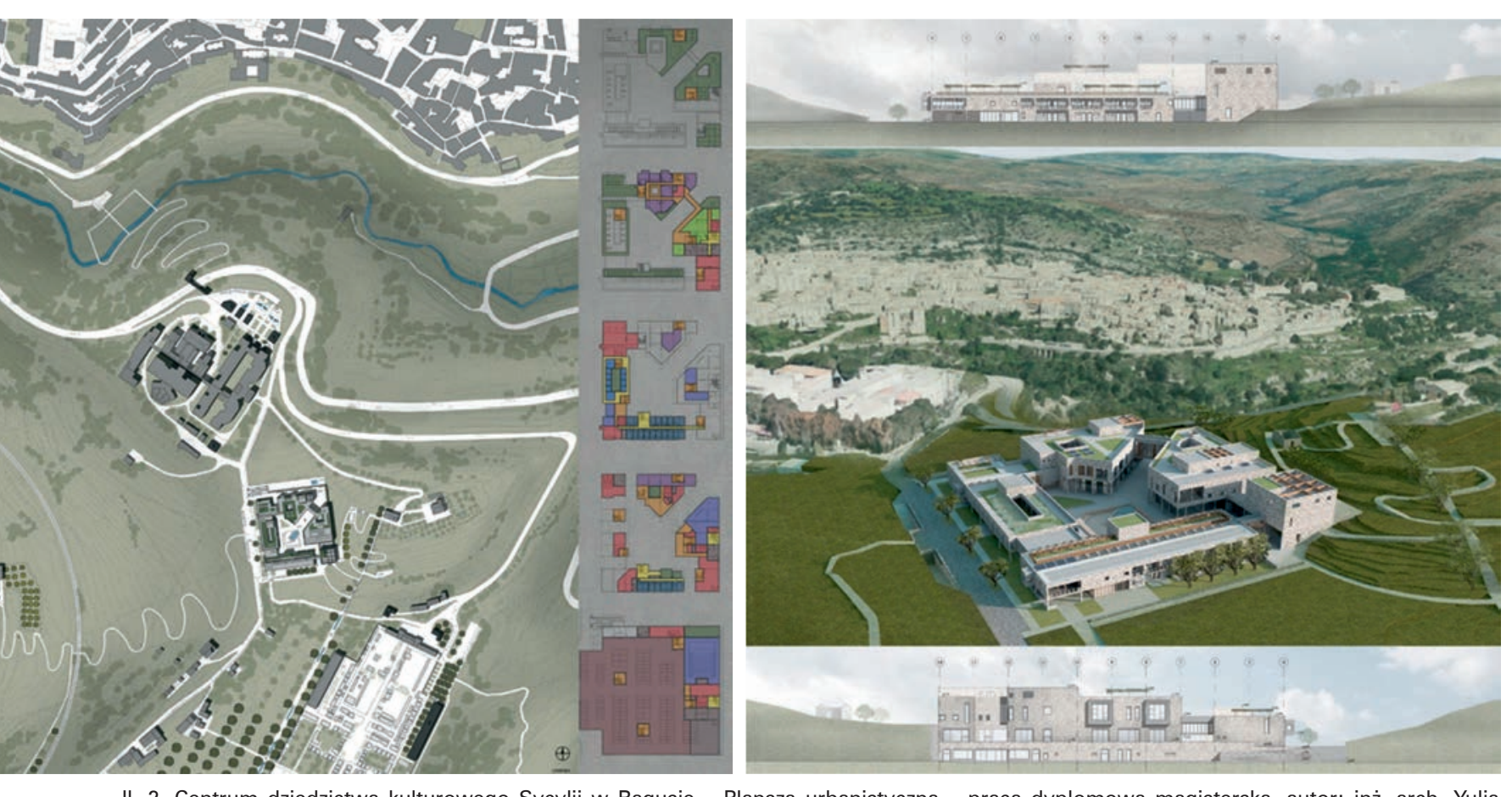

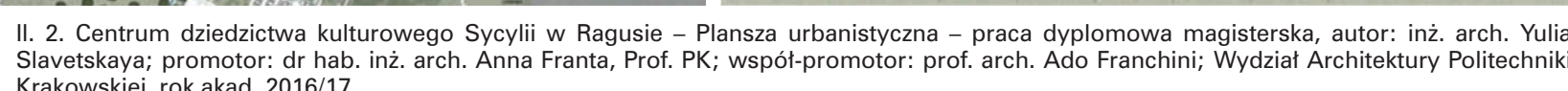

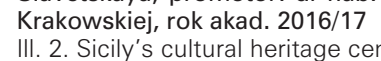

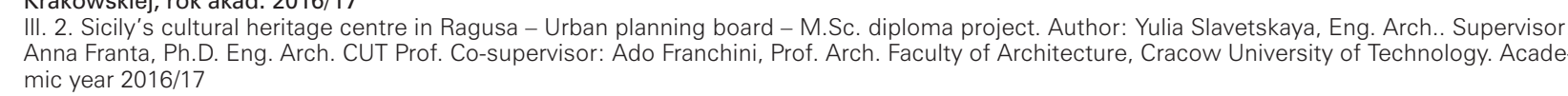

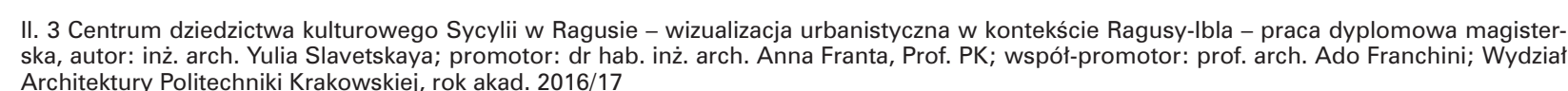

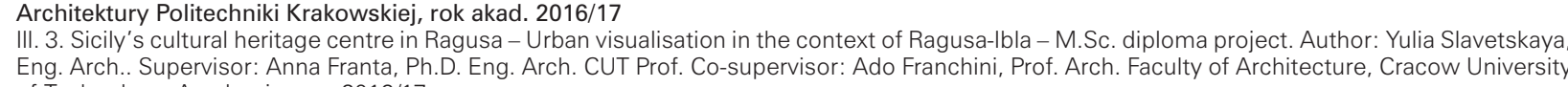
Eng. Arch. Superisisor: Anna ranta, Ph
of Technology. Academic year 2016117

Swoje osobiste doświadczenie wirtualnego poznawania Ragusy i twórczej pracy z jej strukturą, pozwala studentom, by udowodnili samym sobie, a i w wyobrażeniu mieszkańcom miasta, że pozytywne myślenie o projekcie urbanistycznym $i$ architektonicznym może tworzyć perspektywy zwiększające juz istniejące zasoby: z konsekwencja i zdolnoscią dostosowywania się do uwarunkowan miejsc, poszukiwania i prywracania tozsamości urbanistycznej $i$ obywatelskiej miastu poprzez zrównoW ten spośb powstata możliwos

Wość pogłębiania temat (ych wo któzbedne opracowanie planu naprawy, który zrewitalizuje miasto i przywróci je mieszkańcom. Ochroni rozwinie ta miasto i przywón je mieszkañcom. Ochroni i rozwinie ta widecznej, precyzyinej formy zwartego miasta - teraz w jego sercu, a docelowo w całej strukturze.

Dwa tutaj prezentowane - jako przykładowa ilustracja projekty "obszarowe" w dwóch różnych, a kluczowych dla percepcji miasta jako całości, lokalizacjach, posiadaj


przewidziane. Dla obu rozwiązań punktem wyjścia była re-interpretacja, w lokalizacjach poza historycznym centrum historycznego modułu urbanistycznego Ragusy Superior. Oba projekty są też dowodem, że podejście, z pasją i in-
The two area-related designs presented herein as an example of illustration, focusing on two different locations, both of key importance to the perception of the city. 'for the place' for which they have been place' and both solutions the starting point was reinterpretation of the historical urban module of Ragusa Superior in locations beyond the historical city centre. Furthermore, both designs prove that a passionate and intelligent approach, concentrating in a free and conscious way on 'the place' serves to perceive and enhance the values and opportunities revealed by this area - whenever we are able to see with our eyes wide open and observation.

The first design, located beyond the very structure of the city, on the one hand focuses on its incorporation in the tyrl context with two 'urbanised islands': a cemetery and a former psychiatric hospital, and on the other it revex, and in particuar its public spact towards unique views of the oldest part of Ragusa - Ibla, which constitute great advantage of this location, unique in the scale of the entire organism.

The second design, closely associated with the latest structure of the city, looks for a new functional and spatial definition of the outer edge of the city, along the adopt new perspectives for this intentionally creative

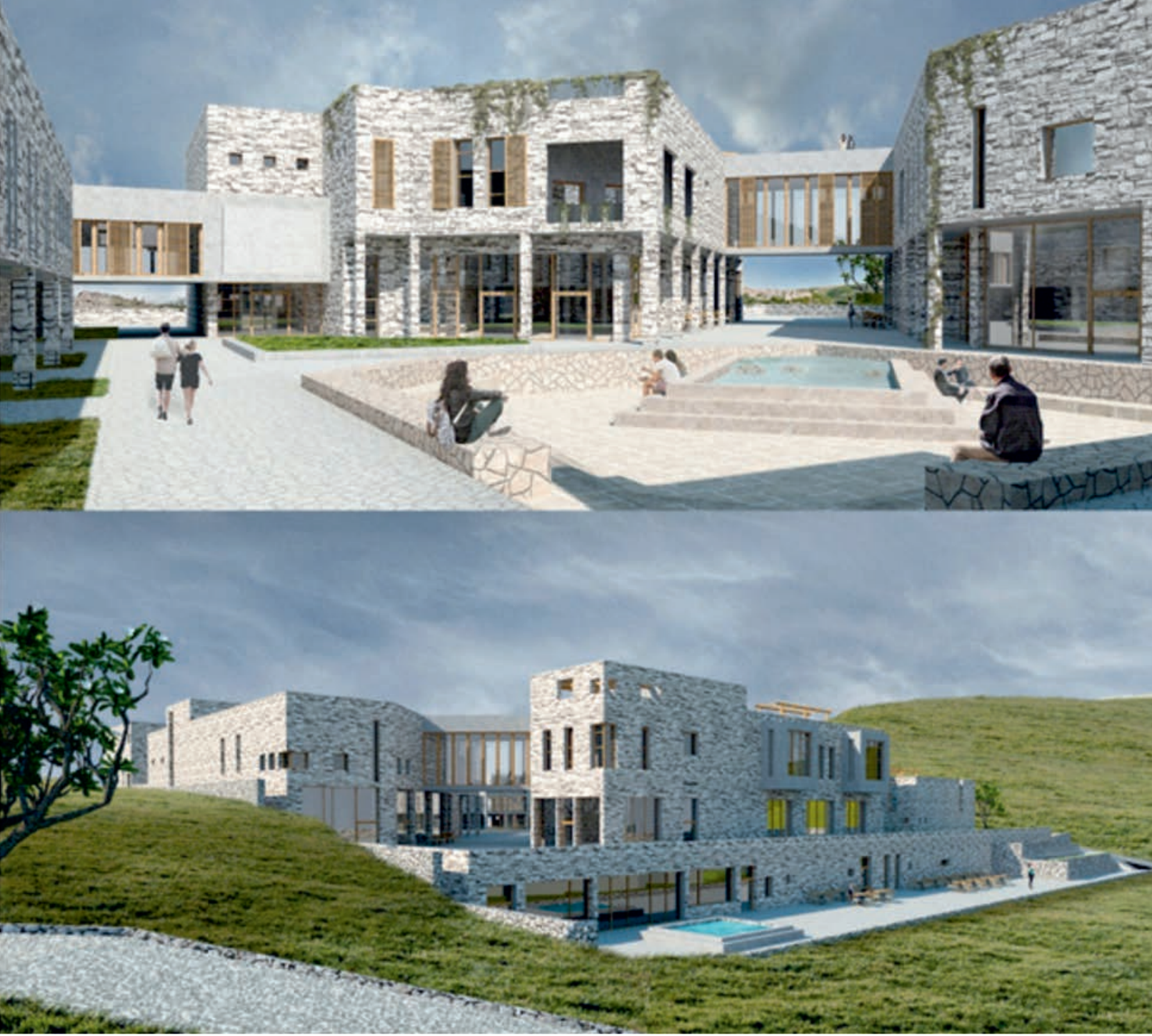

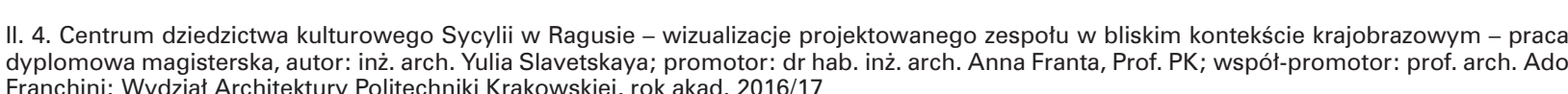

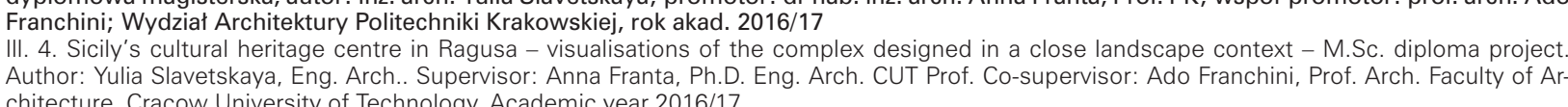

teligencja, skoncentrowane w sposób wolny i świadomy "na miejscu", służy dostrzeżeniu i podniesieniu walorów możliwości, które ujawnia nam teren - wtedy, kiedy potrafimy patrzeć "szeroko otwartymi oczyma" i przyjać nowerspek dy dej, z intencji, twórczej obserwacji. perspektywy dla tej, z intencji, twórczej obserwacji.
Pierwszy projekt - zlokalizowany poza ścisłą strukturą w ruralistyczny kontekstz dwoma 'zurbanizowanymi wyspami': cmentarza i bytego szpita psychiatrycznego. Z drugiej zaś na optymanaj ekspozycji nowego zespotu zzczególnie jego przestrzeni publicznych, na (stanowiace niepowtarzalny w skali catego organizmu miejwiego walor te lok cześć Ragusy - lble.

atomiast drugi projekt, ściśle związany z najnowsza struktura miasta, poszukuje nowej definicji funkcjonalno-przestrzennej zewnettrznej krawędzi miasta - na odcinku uformowanym przez, dzisiaj już nieczynne, kamieniołomy. I to właśnie ich niezwykła tektonika stała się kluczo- section demarcated by the no longer active quarry. An the local tectonics proved to be of key importance for makng decisions relevant to the programme and buildane sense of this place in terns of is compositio and landscape.

Reflection after the Experiment: Ragusa - a Lab City. Naturally, the effect of course and diploma projects is not a product to be used directly. It is not comparable a a flly professional urban plan or design - it remains mere exerise, and as such it cannot be confused with the tool of operational guidelines. In order to make sure that conceptual suggestions and visions will effectively support the process of revitalisation of urban areas, is necessary to translate and interpret the results and to compile a scientific commentary to the effects obtained in the didactic research laboratory.

is important that this idealistic contribution is useful and available to the city, even for the purpose of showing the 


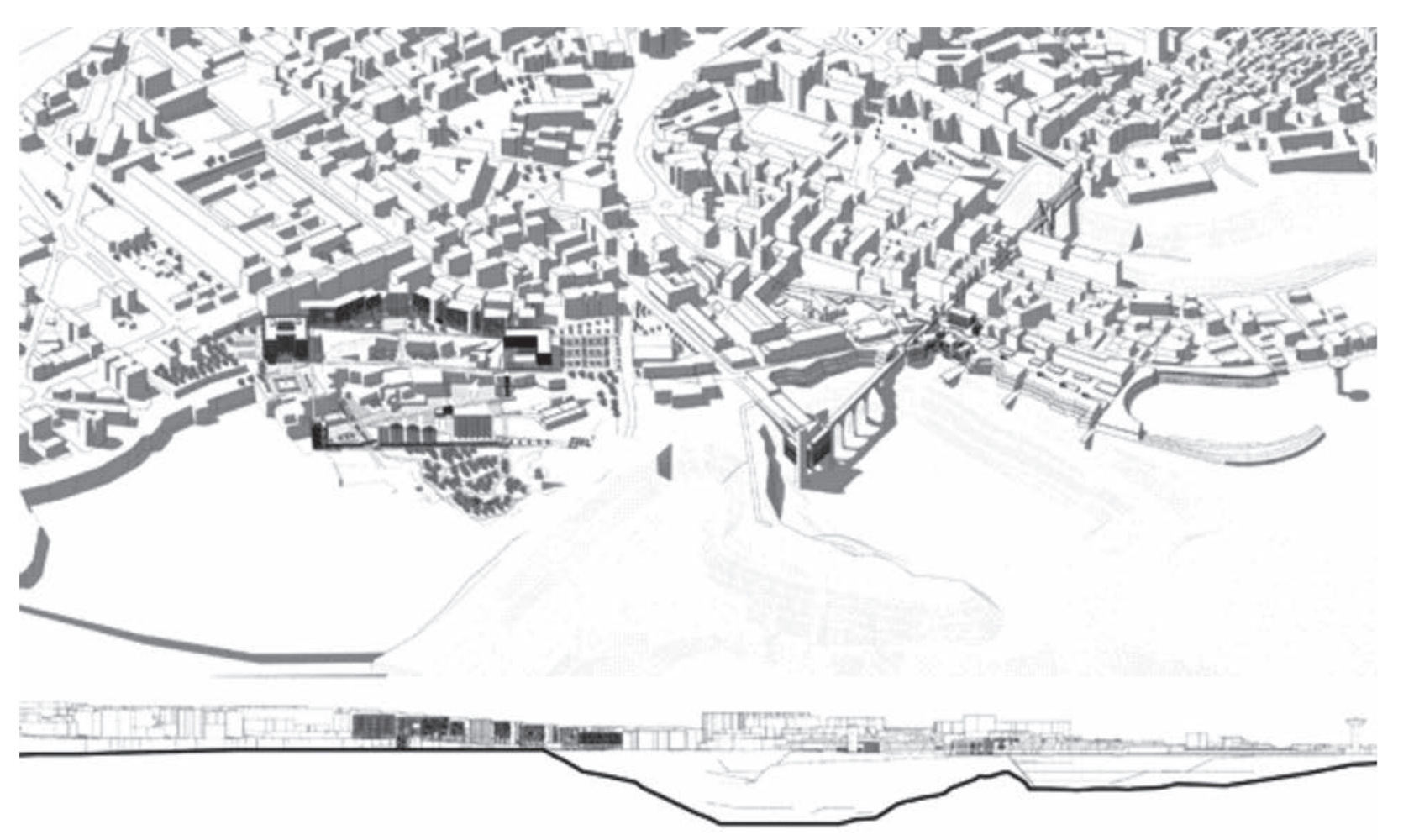
$-\quad-\quad-$
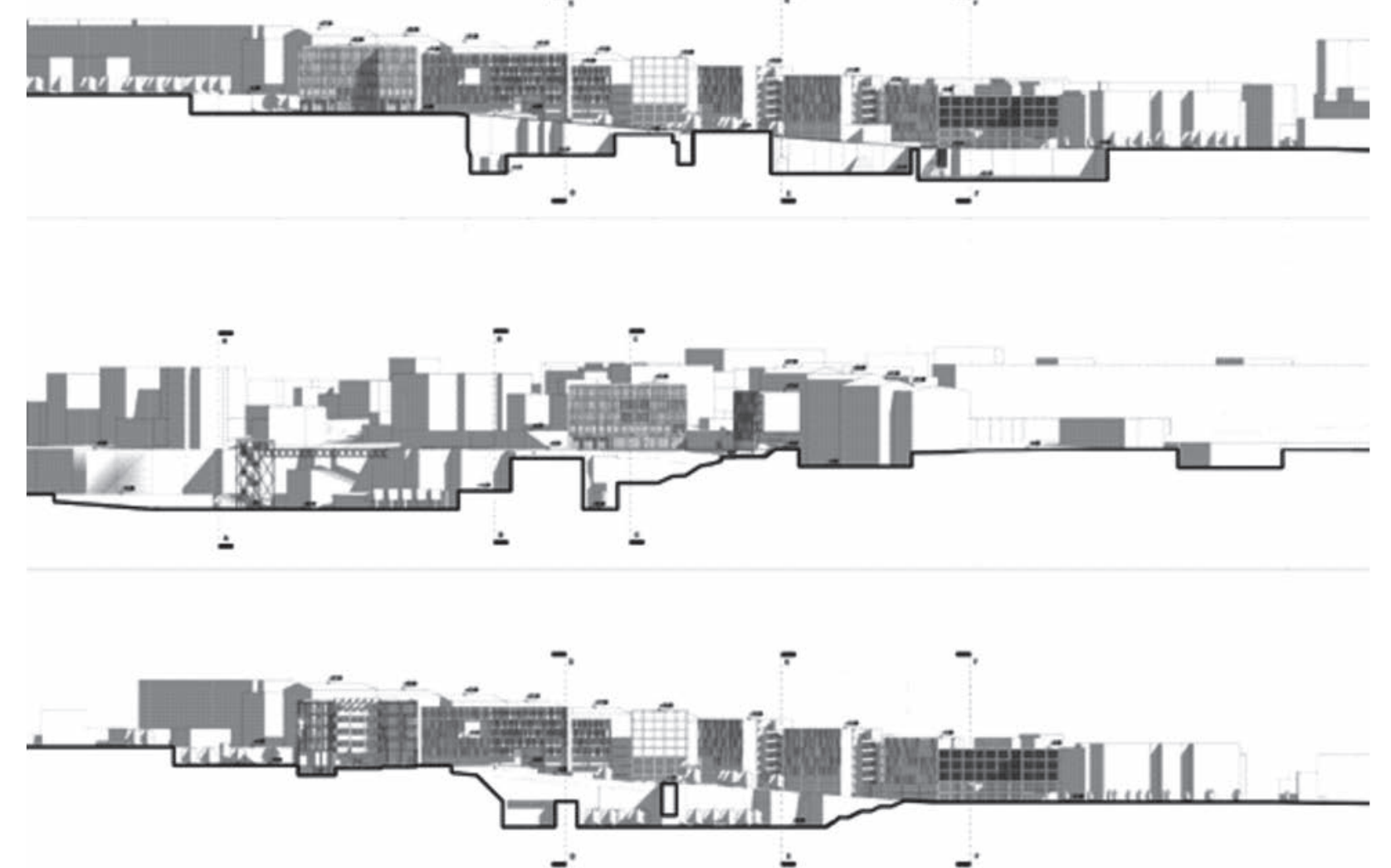

II. 5. Ragusa, Włochy - Scuola di Agraria jako element definiowania post-industrialnej krawedzi miasta - wizualizacja i przzekroje urbanistyczne

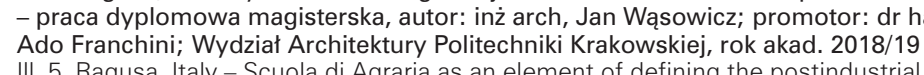

IIII. 5. Ragusa, Italy - Scuola di Agraria as an element of defining the postindustrial edge of the city - urban visualisation and cross sections - M.Sc.
diploma project. Author: Jan Wassowicz, Eng. Arch. Supervisor: Anna Franta, Ph.D. Eng. Arch. CUT Prof. Co-supervisor: Ado Franchini, Prof. Arch. diploma project. Author: Jan Wasowicz, Eng. Arch. Supervisor: Anna Franta, Ph.D. E. E
Faculty of Architecture, Cracow University of Technology, academic year 2018/2019

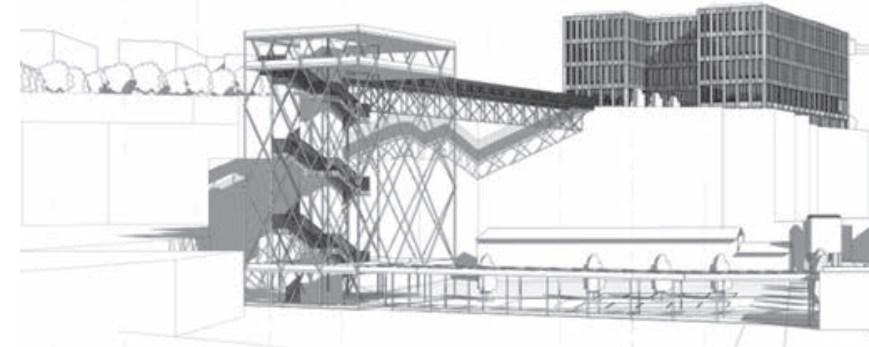

Int

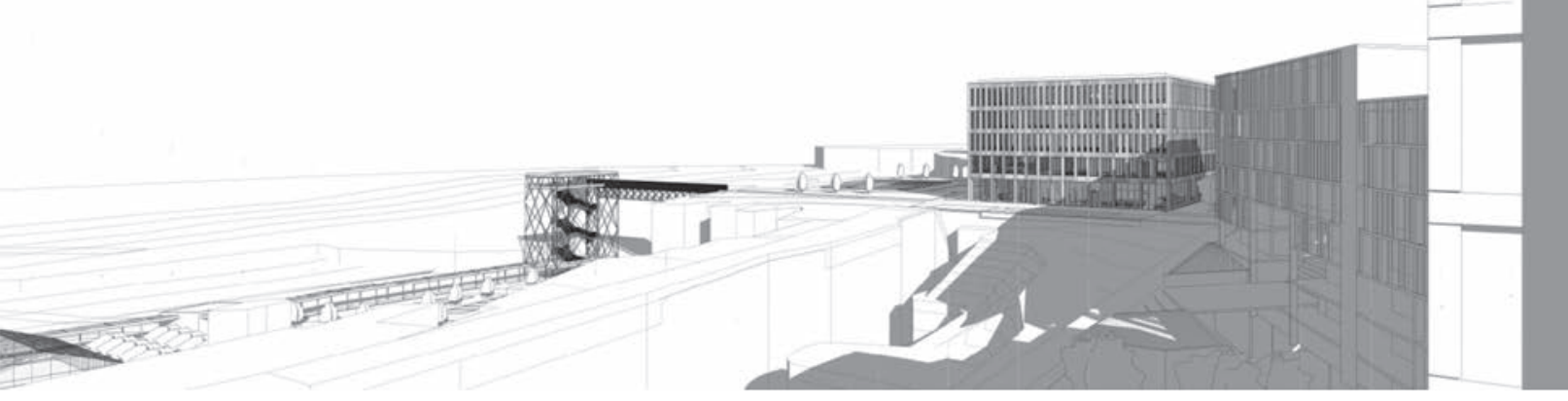

II. 6. Ragusa, Włochy - Scuola di Agraria jako element definiowania post-industrialnej krawedzi miasta - wizualizacja projektowanej kraweddz miasta- praca dyplomowa magisterska, autor: inz arch, Jan Wasowicz; promotor: dria
arch.Ado Franchini; Wydziat Architektury Politechniki Krakowskiej, rok akad. 2018/19

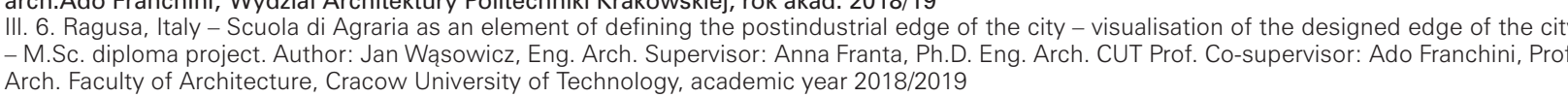

wa, dla podejmowanych decyzji programowych oraz tych budujących kompozycyjny i krajobrazowy sens miejsca.

\section{Refleksja „po" eksperymencie:}

\section{Ragusa - miasto-laboratorium}

Wynik projektow kursowych i dyplomowych nie jest oczywiście produktem bezpośredniego użytku. Nie jest porównywalny do w petni profesjonalnego planu urbanistycznego, czy projektu - pozostaje "cwiczeniem", ktore jako takie, nie może byc mylone z narzędziem wytycznych operacyjnych. Aby upewnic się, ze sugestie i wizje ideowe efektywnie

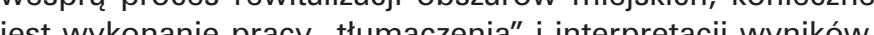



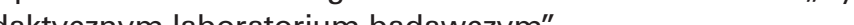

"idealistyczny" wkład stał się przydatny, pozostał do dyspozycji miasta choćby w celu pokazywania społeczności lokalnej wachlarza możliwych działan. W rzeczywistości proces przebudowy, przechodzi przez rewizję narzedzi planowania urbanistycznego, ale na wcześnieiszym etapie nawet te studialne" rezultaty moga przyczynić sie do zdefiniowania nowego pomysłu na miasto.

Tak więc podsumowując związki badań naukowych - dotyzących wyzwań przed jakimi stoja szeroko pojete historyczne centra miast $-z$ "laboratorium dydaktycznym" trzeba stwierdzić, że uzyskane w wyniku procesu dydaktycznego rezultaty projektowe można traktowac jako swoiste 'dane do analizy'. Wariantowe podejścia ideowe do zagadnienia, dają możliwość analizy porownawczej konsekwencji okreslonego rozwiązania local community the range of possible measures. In a certain revision of urban planning tools, but at the earler stage even such theoretical results can contribute to the definition of a new idea for the city. research deved to up the connections between Iy understood historical centres of cities and 'the didactic laboratory', it needs to be concluded that the design results obtained in the didactic process can be regarded as specific data for further analyoffer a possibility of a comparative analysis of consequences of a specific solution for the structure the city; hence they can be helpful in the process of measure optimisation. On the other hand, on thorough large-scale study conducted in a polemic dialogue with the planning conditions in force, and each diploma project is such a sudy, can constitu a fully-fredged verification of the theses made in the process of studying the city.

challenges faced byde the simulations and designing proposals, frequently quite experimental and bold in nature, can be used by city authorities in the urban planning practice and open new fields for further discussions, conducted not only amongst professionals and scientists, bu also with participation of city residents. 
dla struktury miasta - i stąd, mogą być pomocne w procesie optymalizacji działań. Natomiast jedno, pogłębione i wielo-skalarne studium, prowadzone w polemicznym dialogu z obowiązującymi uwarunkowaniami planistycznymi, jakimi są prace dyplomowe, może już być pełnowartościowym sprawdzeniem projektowym postawionych w procesie badawczym miasta tez. Natomiast wobec przyszłych wyzwań - w tym doskonalenia ich struktury - przed jakimi stają szeroko pojęte historyczne centra, takie symulacje i propozycje projektowe, nieraz o eksperymentalnym, śmiałym charakterze, mogą być wykorzystywane przez władze miast w praktyce urbanistycznej i otwierać pola do dalszych dyskusji prowadzonych, nie tylko w gronie profesjonalistów i naukowców, ale i z udziałem mieszkańców.

Bowiem do roli społeczności lokalnej - jako interaktywnego partnera - należy ekspresja indywidualnych i grupowych oczekiwań i potrzeb, ale też rozwój samoświadomości przestrzennej: wrażliwości, rozumienia znaczenia wartościowej przestrzeni publicznej indywidualnie dla każdego i zbiorowości. Wtedy możliwe jest zaistnienie pozytywnej presji społecznej - wspieranie działań architektów-urbanistów, traktowanych jako godnych zaufania, fachowych reprezentantów potrzeb społeczności lokalnej, mogących, z racji fachowości odpowiedzieć na te potrzeby optymalnym rozwiązaniem. Rozwiązaniem, które ma, dzięki swej jakości, naturalną siłę przekonywania, że rolą architektury w sposób szczególny tej tworzącej przestrzeń publiczną miasta - jest nie tylko zaspokojenie potrzeb, ale ich stymulowanie (i potem zaspokajanie). I również nie schlebianie gustom (modom) lub ich apodyktyczne narzucanie, a ich rozwijanie, wyrabianie, przez lansowanie i wprowadzanie dobrych wzorów w zgodzie ze specyfiką i tożsamością miejsca, w więc lokalnych społeczności i ich potrzeb w zakresie zindywidualizowanej ekspresji (9). Zważywszy, że obowiązuje nas wszystkich służebność wobec elementarnego, piękna które „tworzą tak nieliczni a potrzebuje tak wielu" (Goethe).

\section{LITERATURA}

[1] R. Rogers, The Culture of Cities, [w:] Richard Rogers Partnership Works and Projects, Monacelli Press, New York 1996

[2] U. Eco, Pejzaż semiotyczny, PIW, Warszawa, 1972

[3] A. Franta, Reżyseria przestrzeni. O doskonaleniu przestrzeni publicznej miasta, Politechnika Krakowska, Kraków, 2004

[4] A. Franta, Search of the Quality of City Public Space. Space Directing - Tool of Improvement, IOP Conference Series: Materials Science and Enginering, vol. 471 1-9. DOI:10.1088/1757-899X/471/9/092029

[5] P. Bess, Till we have built 'Jerusalem'- Architecture, Urbanism and the Sacred, I.S.I. Books, Delawere, Wilmington, 2006 s.9.

[6] W. Kosiński, Paradygmat miasta XXI wieku, Politechnika Krakowska, Kraków, 2016

[7] Education for Research - Research for Creativity, edited by: J. Słyk \& L. Bezeera, Politechnika Warszawska, Warszawa 2016

[8] Walking the City. Barcelona as an Urban Experience, E. Roca, I. Aquilue,

R. Gomes (eds.). University of Barcelona, ISBN 978-84-475-3878-2

[9] B. Podhalański, Ikoniczność metropolii, Politechnika Krakowska, Kraków, 2019
It is the role of the local community as an interactive partner to express individual and collective expectations and needs, but also to develop spatial self-awareness: sensitivity, understanding the meaning of a valuable public space individually for everyone and in a community. Then it is possible to have a positive social pressure - supporting activities of architects and urban planners, regarded as trustworthy and competent representatives of the needs of the local community, capable of fulfilling such needs with an optimal solution thanks to their professionalism. A solution which thanks to its quality has a natural ability to convince that the role of architecture, and particularly of the architecture that creates the public space of the city, is not merely satisfying the needs, but stimulating them (and subsequently satisfying them). It is not about catering to the tastes (fashions) or imposing them overbearingly, but about developing, mustering them by the promotion and introduction of good patterns in compliance with the specificity and identity of the place and in line with local communities and their needs in terms of individualised expression (9).

Always bearing in mind that we are all obliged to serve the elementary beauty, which "is created by so few and is needed by so many" (Goethe).

\section{BIBLIOGRAPHY}

[1] R. Rogers, The Culture of Cities, [in:] Richard Rogers Partnership Works and Projects, Monacelli Press, New York 1996.

[2] U. Eco, Pejzaż semiotyczny, PIW, Warsaw, 1972

[3] A. Franta, Reżyseria przestrzeni. O doskonaleniu przestrzeni publicznej miasta, Cracow University of Technology, Cracow, 2004

[4] A. Franta, Search of the Quality of City Public Space. Space Directing - Tool of Improvement, IOP Conference Series: Materials Science and Enginering, vol. 471 1-9. DOI:10.1088/1757-899X/471/9/092029

[5] P. Bess, Till we have built 'Jerusalem'- Architecture, Urbanism and the Sacred, I.S.I. Books, Delawere, Wilmington, 2006 s.9.

[6] W. Kosiński, Paradygmat miasta XXI wieku, Cracow University of Technology, Cracow, 2016

[7] Education for Research - Research for Creativity, edited by: J. Słyk \& L. Bezeera, Politechnika Warszawska, Warsaw 2016

[8] Walking the City. Barcelona as an Urban Experience, E. Roca, I. Aquilue, R. Gomes (eds.),University of Barcelona, ISBN 978-84-475-3878-2

[9] B.Podhalański, Ikoniczność metropolii, Cracow University of Technology, Cracow, 2019 